\section{Collard Cultivar Evaluations in Northern Florida}

\author{
Stephen M. Olson ${ }^{1}$ and Joshua H. Freeman ${ }^{2,3}$
}

AdDITIONAL INDEX WORDS. Brassicaceae, variety trial, yield, Brassica olevacea

SumMARY. Nine collard (Brassica olevacea acephala group) cultivars were evaluated on six experiments over 4 years to determine how well they performed with respect to yield, plant weight, and bolting tolerance. Experiments covered spring, fall, and winter seasons to determine if one cultivar would be useful for all conditions. 'Top Pick', 'Flash', and 'Blue Max' were found to be the best performing cultivars with respect to yield and plant weight. In general, the hybrid cultivars outperformed the open-pollinated cultivars. Only during one experiment were the cultivars subjected to environmental conditions favorable for bolting, but there were no significant differences in incidence of bolting among the cultivars. Although top-performing cultivars were hybrids, the cost associated with hybrid seed must be considered.

$\mathrm{C}$ ollard greens are a primitive member of the Brassicaceae that are grown for their rosette of thick, dark green leaves, which are eaten primarily as cooked greens or pot herbs. Collards, along with most greens, are an excellent source of fiber, vitamins $\mathrm{A}$ and $\mathrm{C}$ as well as minerals (Peirce, 1987). The acephala group of Brassica oleracea, which includes collard and kale, are thought to have originated in western Europe or the Mediterranean (Boswell, 1949; Rubatzky and Yamaguchi, 1997). Collards traditionally have been a crop that was grown primarily during cool seasons in the southern and eastern United States. However, expanding markets have led to yearround production in some areas. The last year in which the U.S. Department of Agriculture collected production data on collards was 2001 . In that year, there were 14,100 acres of collards harvested in the United States with the primary production states being Georgia, North Carolina, South Carolina, and Alabama (U.S. Department of Agriculture, 2001).

Collards are tolerant of a wide range of temperatures, but bolting may be initiated by prolonged exposure to cold temperatures, $40{ }^{\circ} \mathrm{F}$ or less, followed by a period of warmer weather (Peirce, 1987). Multiple

${ }^{1}$ Department of Horticultural Sciences, University of Florida, North Florida Research and Education Center, 155 Research Road, Quincy, FL 32351

${ }^{2}$ Department of Horticulture, Virginia Polytechnic Institute, and State University, Eastern Shore Agricultural Research and Extension Center, 33446 Research Drive, Painter, VA 23420

${ }^{3}$ Corresponding author. E-mail: joshfree@vt.edu. open-pollinated and hybrid collard cultivars are available that vary in phenotypic characteristics, tolerance to disease and environmental conditions, and tendency to exhibit nutritional disorders (Dufault et al., 1992; Farnham and Garrett, 1996; Farnham et al., 2001; Johnson, 1991).

The objective of this research was to evaluate collard cultivars over multiple seasons to determine the topperforming cultivars for the northern Florida and southern Georgia growing areas.

\section{Materials and methods}

Experiments were performed at the North Florida Research and Education Center (NFREC) in Quincy, FL, between 2003 and 2006. Soil type at NFREC was Norfolk loamy sand (fine-loamy, kaolinitic, thermic Typic Kandiudults). Six experiments were conducted using nine collard cultivars. Cultivars evaluated were 'Blue Max', 'Champion', 'Flash', 'Georgia', 'Heavi-Crop', 'Morris Heading', 'Top Bunch', 'Top Pick', and 'Vates'. These cultivars were chosen because they are a representation of nearly all commercially available collard cultivars that were available during the entire experiment. Five of the cultivars used were hybrids ('Blue Max', 'Flash', 'HeaviCrop', 'Top Bunch', 'Top Pick') and four cultivars were open-pollinated ('Champion', 'Georgia', 'Morris Heading', 'Vates'). Complete cultivar information is presented in Table 1.

Seeds were sown in the greenhouse into expanded polystyrene flats of the inverted pyramid design with cell dimensions of $1 \times 1 \times 3$ inches deep. Seedlings were grown for 4 to 6 weeks before transplanting, depending on season. Plots consisted of a single row $26 \mathrm{ft}$ long with betweenrow spacing of $3 \mathrm{ft}$ and in-row spacing of 12 inches corresponding to a planting density of 24 plants/plot and 14,520 plants/acre. Fertilizer was applied at a rate of $160 \mathrm{lb} /$ acre nitrogen, $35 \mathrm{lb} /$ acre phosphorus, and $66 \mathrm{lb} /$ acre potassium. Fertilization was based on University of Florida Institute of Food and Agricultural Sciences (UF-IFAS) recommendations (Olson et al., 2006). Experimental design was a randomized complete block with four replications on each experiment. Pest management practices recommended by UF-IFAS were used as needed (Olson et al., 2006). Overhead irrigation was used to supplement rainfall as needed.

Once-over harvests of marketable collard plants were made at 74 , $73,66,104,71$, and $73 \mathrm{~d}$ after transplant for the six experiments (the following dates are transplant dates: 11 Sept. 2003, 9 Mar. 2004, 24 Sept. 2004, 11 Jan. 2005, 3 Oct. 2005, 25 Sept. 2006, respectively). Plants that had bolted or exhibited a growth habit different from the remainder of the plot were considered nonmarketable or an off-type and not included in yield data. Yield from individual plots was converted to number of $25-1 b$ boxes per acre. Analysis of variance for yield and average plant weight was performed using the GLM procedures of SAS (version 9.1; SAS Institute, Cary, NC) and means separation was accomplished using Duncan's multiple range test.

\begin{tabular}{llll}
\hline $\begin{array}{l}\text { Units } \\
\text { To convert U.S. to SI, } \\
\text { multiply by }\end{array}$ & U.S unit & SI unit & $\begin{array}{l}\text { To convert SI to U.S., } \\
\text { multiply by }\end{array}$ \\
\hline 0.4047 & $\mathrm{acre}(\mathrm{s})$ & $\mathrm{ha}$ & 2.4711 \\
0.3048 & $\mathrm{ft}$ & $\mathrm{m}$ & 3.2808 \\
2.54 & $\mathrm{inch}(\mathrm{es})$ & $\mathrm{cm}$ & 0.3937 \\
0.4536 & $\mathrm{lb}$ & $\mathrm{kg}$ & 2.2046 \\
1.1209 & $\mathrm{lb} / \mathrm{acre}$ & $\mathrm{kg} \cdot \mathrm{ha}^{-1}$ & 0.8922 \\
$\left({ }^{\circ} \mathrm{F}-32\right) \div 1.8$ & ${ }^{\circ} \mathrm{F}$ & ${ }^{\circ} \mathrm{C}$ & $\left(1.8 \times{ }^{\circ} \mathrm{C}\right)+32$
\end{tabular}




\section{Results and discussion}

Collard cultivar significantly affected yield and plant weight but did not affect the percentage of bolted plants. Complete yield and plant weight data are presented in Tables 2 and 3 .

Cultivar averages are discussed because they provide the greatest insight into the cultivars' performance. The top-yielding cultivar was 'Top Pick', which produced 1996 boxes/acre; however, it was not significantly greater than 'Flash', 'Blue Max', or 'Top Bunch' at 1922, 1868, and 1762 boxes/acre, respectively (Table 2). 'Top Pick' did yield significantly more boxes per acre than the remaining cultivars. There were no significant differences in yield among 'Flash', 'Blue Max', 'Top Bunch', 'Heavi-Crop', and 'Morris Heading'. 'Flash' and 'Blue Max' did yield significantly more boxes per acre than 'Champion', 'Vates', and 'Georgia', but 'Morris Heading', Heavi-Crop', and 'Top Bunch' did not.

'Top Pick' had the largest plant weight at $3.5 \mathrm{lb}$, which was not significantly greater than 'Flash' and 'Blue Max' at $3.3 \mathrm{lb}$ (Table 3). There were no significant differences in plant weight among 'Flash', 'Blue Max', 'Morris Heading', 'HeaviCrop', 'Champion', and 'Top Bunch'. 'Georgia' produced plants with the lowest weight but were not significantly different from 'Vates', 'Top Bunch', 'Champion', 'HeaviCrop', or 'Morris Heading'.

During the crop that was planted on 11 Jan. 2005, conditions were favorable for bolting and some plots exhibited bolting in up to $100 \%$ of the plants. Average percentage of bolted plants by cultivar ranged from $7 \%$ to 31\% (data not presented). Although bolting was prevalent, variability was such that cultivar did not significantly affect the percentage of bolted plants.

These cultivar evaluations were performed during a wide range of environmental conditions that are representative of nearly all environments in which collard are produced. The top-performing cultivars for both plant weight and yield were 'Top Pick', 'Flash', and 'Blue Max', all hybrid cultivars. In both categories, 'Top Pick' outperformed all open-pollinated cultivars and yielded

Table 1. Collard cultivars evaluated on multiple planting dates in Quincy, FL, from 2003 through 2006.

\begin{tabular}{llc}
\hline Cultivar & \multicolumn{1}{c}{ Seed source } & $\begin{array}{c}\text { Hybrid or } \\
\text { open-pollinated (OP) }\end{array}$ \\
\hline Blue Max & American Takii, Salinas, CA & Hybrid \\
Champion & Multiple sources & OP \\
Flash & Sakata Seeds America, Morgan Hill, CA & Hybrid \\
Georgia & Multiple sources & OP \\
Heavi-Crop & American Takii & Hybrid \\
Morris Heading & Multiple sources & OP \\
Top Bunch & Sakata Seeds America & Hybrid \\
Top Pick & Sakata Seeds America & Hybrid \\
Vates & Multiple sources & OP \\
\hline
\end{tabular}

Table 2. Collard cultivar yield data from cultivar evaluations in Quincy, FL, during 2003 through 2006.

\begin{tabular}{|c|c|c|c|c|c|c|c|}
\hline \multirow[b]{2}{*}{ Cultivar } & \multicolumn{7}{|c|}{ Yield [no. 25-lb (11.3 kg) boxes/acre] ${ }^{\mathrm{z}}$} \\
\hline & $\begin{array}{c}11 \text { Sept. } \\
2003^{\mathrm{y}}\end{array}$ & $\begin{array}{c}9 \text { Mar. } \\
2004\end{array}$ & $\begin{array}{l}24 \text { Sept. } \\
2004\end{array}$ & $\begin{array}{c}11 \mathrm{Jan} . \\
2005\end{array}$ & $\begin{array}{l}3 \text { Oct. } \\
2005\end{array}$ & $\begin{array}{c}25 \text { Sept. } \\
2006\end{array}$ & $\begin{array}{c}\text { Cultivar } \\
\text { avg }^{\mathrm{x}}\end{array}$ \\
\hline Top Pick & 2,342 & 2,613 & 1,230 & 2,202 & 1,973 & 1,613 & $1,996 \mathrm{a}$ \\
\hline Flash & 2,273 & 2,701 & 1,374 & 1,561 & 1,921 & 1,704 & $1,922 \mathrm{ab}$ \\
\hline Blue Max & 2,033 & 2,541 & 1,536 & 1,890 & 1,717 & 1,490 & $1,868 \mathrm{ab}$ \\
\hline Top Bunch & 1,909 & 2,919 & 1,056 & 1,230 & 1,771 & 1,689 & $1,762 \mathrm{abc}$ \\
\hline Heavi-Crop & 1,727 & 2,245 & 1,005 & 2,114 & 1,510 & 1,448 & $1,675 \mathrm{bc}$ \\
\hline Morris Heading & 1,635 & 2,182 & 1,102 & 1,981 & 1,434 & 1,648 & $1,664 \mathrm{bc}$ \\
\hline Champion & 1,478 & 2,206 & 953 & 2,223 & 1,598 & 1,392 & $1,642 \mathrm{c}$ \\
\hline Vates & 1,672 & 1,993 & 1,102 & 1,410 & 1,597 & 1,657 & $1,572 \mathrm{c}$ \\
\hline Georgia & 1,700 & 1,907 & 1,104 & 1,482 & 1,459 & 1,530 & $1,530 \mathrm{c}$ \\
\hline
\end{tabular}

${ }^{2}$ Yield estimates are based on plant populations of 14,520 plants/acre $(35,879.7$ plants $/$ ha $) ; 1$ box $/$ acre $=28.0213$ $\mathrm{kg} \cdot \mathrm{ha}^{-1}$

'Dates are planting dates.

${ }^{x}$ Means with the same letter are not significantly different at $P \leq 0.05$ by least significant difference.

Table 3. Collard cultivar head weight data from cultivar evaluations in Quincy, FL, during 2003 through 2006.

\begin{tabular}{|c|c|c|c|c|c|c|c|}
\hline \multirow[b]{2}{*}{ Cultivar } & \multicolumn{7}{|c|}{ Head wt $(1 b)^{z}$} \\
\hline & $\begin{array}{l}11 \text { Sept. } \\
2003^{y}\end{array}$ & $\begin{array}{c}9 \text { Mar. } \\
2004\end{array}$ & $\begin{array}{l}24 \text { Sept. } \\
2004\end{array}$ & $\begin{array}{c}11 \mathrm{Jan} . \\
2005\end{array}$ & $\begin{array}{l}3 \text { Oct. } \\
2005\end{array}$ & $\begin{array}{l}25 \text { Sept. } \\
2006\end{array}$ & $\begin{array}{c}\text { Cultivar } \\
\text { avg }^{\mathrm{x}}\end{array}$ \\
\hline Top Pick & 4.1 & 4.5 & 2.1 & 4.1 & 3.4 & 2.8 & $3.5 \mathrm{a}$ \\
\hline Flash & 4.0 & 4.6 & 2.3 & 2.8 & 3.3 & 2.9 & $3.3 \mathrm{ab}$ \\
\hline Blue Max & 3.5 & 4.3 & 2.6 & 3.5 & 2.9 & 2.8 & $3.3 \mathrm{ab}$ \\
\hline Morris Heading & 3.0 & 3.7 & 1.9 & 3.9 & 2.4 & 2.8 & $3.0 \mathrm{bc}$ \\
\hline Heavi-Crop & 3.0 & 3.8 & 1.7 & 3.9 & 2.6 & 2.5 & $2.9 \mathrm{bc}$ \\
\hline Champion & 2.5 & 3.6 & 1.6 & 4.4 & 2.7 & 2.6 & $2.9 \mathrm{bc}$ \\
\hline Top Bunch & 3.2 & 4.3 & 1.9 & 2.2 & 3.0 & 2.9 & $2.9 \mathrm{bc}$ \\
\hline Vates & 2.9 & 3.4 & 1.9 & 3.3 & 2.7 & 2.9 & $2.8 \mathrm{c}$ \\
\hline Georgia & 3.0 & 3.2 & 2.0 & 2.6 & 2.5 & 2.6 & $2.6 \mathrm{c}$ \\
\hline
\end{tabular}

${ }^{\mathrm{z}} \mathrm{l} \mathrm{lb}=0.4536 \mathrm{~kg}$.

y Dates are planting dates.

${ }^{x}$ Means with the same letter are not significantly different at $P \leq 0.05$ by least significant difference.

greater than the hybrid 'Heavi-Crop'. Other hybrid cultivars also performed well but did not yield significantly greater than all open-pollinated cultivars. There were no significant differences in yield among the openpollinated cultivars. No response in bolting tolerance was observed between or among hybrids or openpollinated cultivars.
Although the hybrid cultivars performed well, the cost of hybrid seed must be taken into consideration because it can be 10 to 15 times greater than open-pollinated seed.

'Top Bunch' performed as well as the top three cultivars with respect to yield, but may be expected to produce significantly smaller plants than these cultivars. 'Top Pick', 
VARIETY TRIALS

'Flash', or 'Blue Max' collards would most likely be the best performing collard cultivars for the northern Florida and southern Georgia growing areas under most environmental conditions.

\section{Literature cited}

Boswell, V.R. 1949. Our vegetable travelers. Natl. Geogr. Mag. 96:145217.

Dufault, R.J., K.D. Batal, D. Decoteau, J.T. Garrett, D. Granberry, W. McLaurin, R. Nagata, K.B. Perry, and D. Sanders. 1992. Scheduling collard planting dates regionally to lengthen the production period. Hort Technolgy 2:64-66.

Farnham, M.W. and J.T. Garrett. 1996. Importance of collard and kale genotype for winter production in southeastern United States. HortScience 31:1210-1214.

Farnham, M.W., A.P. Keinath, and J.P. Smith. 2001. Characterization of fusarium yellows resistance in collard. Plant Dis. 85:890-894.

Johnson, J.R. 1991. Calcium nutrition and cultivar influence incidence of tipburn of collard. HortScience 26:544-546.

Olson, S.M., E.H. Simonne, W.M. Stall, M.T. Momol, S.E. Webb, T.G. Taylor, and S.A. Smith. 2006. Cole crop production in Florida, p. 141-186. In: Olson, M. Vegetable production handbook for Florida. Univ. Florida Coop. Ext. Serv., Vance Publishing, Lenexa, KS.

Peirce, L.C. 1987. Vegetables-Characteristics, production, and marketing. Wiley, New York, NY.

Rubatzky, V.E. and M. Yamaguchi. 1997. World vegetables, 2nd ed. Chapman \& Hall, New York, NY.

U.S. Department of Agriculture. 2001. Quick stats. 20 May 2007. <http:// www.nass.usda.gov/QuickStats/Create_ Federal_All.jsp>. 